\title{
The improvement of students' moral reasoning through the intelligent character education of classical formats model
}

\author{
M Iswari ${ }^{1}$, Neviyarni ${ }^{2}$, R Hayati $^{3}$ \\ \{mega_iswari@yahoo.com\} \\ 1,2,3 Universitas Negeri Padang, Jl. Prof Dr. Hamka Air Tawar, Padang, Indonesia
}

\begin{abstract}
This study aims to examine the effectiveness of the guidance and counseling services by the intelligent character education model of classical format (PKC-KA) to improve the students' moral reasoning. Intelligence is proposed specifically since it is not enough for the students to have character only. They need intelligence to complete character because these two are the perfection of reason to think and understand in order to sharpen mind in every action. This research used an experimental method. The population of the study was postgraduate students and the researchers took the students of Guidance and Counseling as the sample. The sampling technique used was cluster sampling. The data were analyzed using Kolmogorov Smirnov 2 Independent Samples. The results of the study found that guidance and counseling services with the intelligent character education model of classical format (PKC-KA) were effective to improve the students' moral reasoning.
\end{abstract}

\section{Introduction}

The Indonesian Law concerning the National Education System No. 20 year 2003 article 3 states that national education functions to develop the ability and shape of dignified national character and civilization in order to educate the lives of the nation, aimed at developing the potential of students to become human beings who believe and are devoted to God Almighty, noble, healthy, knowledgeable, capable, creative, independent, become a democratic and responsible citizen.

At this time, the students have various problems related to moral issues that often occur in society. These problems need a reasoning skill that called moral reasoning. Moral reasoning is a person's ability to achieve a higher cognitive level so that they are able to think about moral issues to be more complex [1]. If someone's moral reasoning is high according to the stages of development, thus his/her moral level will be higher too. The development of human moral reasoning consists of three levels: pre-conventional, conventional, and postconventional level of reasoning [2]. It is closely related to the education life on campus. The intelligent character education of classical format makes the students understand and implement moral values in everyday life and have a good self-concept too. Ideally, the concept of self and parental support influence learning motivation. Additionally, the positive self-concept is a positive view of the state of self and feel confident with the abilities possessed, thus it can lead to self-confidence and self-esteem. This self-esteem which can be meant as an evaluation of oneself will determine the extent to which the students are confident in their abilities and achievement [3]. 
In this paper, the study focused on the students' reasoning with intelligent character education of classical format model. This model can be implemented in educational units and intended to assist personal development that is aware of character-intelligent values and practices them. It creates an environment that is thickly colored by character-intelligent values, such as the implementation of the noble values of Pancasila. Then, the individual thinking or cognitive potential determines how individuals react in making a decision and achieving happiness. Overall, the potential for thinking can be either rational or irrational, determines individuals' behavior and feeling [4].

PKC-KA implementation brings the educators and students together to get high meaningful learning that is realized through the Thinking, Feeling, Acting, Acting and Responsible (BMB3) strategy [5] [6]. The BMB3 is activated by the educators or facilitators for the students or PKC-KA participants. This activation takes place actual and contextual, clear and related, continuous and consistent in accordance with the level of ability (development) of the students towards the learning material being discussed. The BMB3 strategy avoids the transactional learning process by the educators or facilitators towards the students or PKC-KA participants, yet it presents a transformative learning process. However, the formulation of intelligent character value items is very vital. How the intelligent character can be understood if the formula does not exist; cannot be heard and/or read; even to be understood. It can not be understood nor applied. Moreover, how the components derived from the five general focus of the smart character (i.e. faith and piety, honest, intelligent, tough and caring).

\section{Method}

This study used an experimental method. The research population was postgraduate students, while the research sample was students of Guidance and Counseling course. The study used cluster sampling technique. The experimental sample was divided into two groups which aimed to see the consistency of the treatment given. Both groups were given a classical counseling guidance treatment using the intelligent character education of classical format model (PKC-KA). The number of samples in group 1 was 25 students and group 2 was 25 students. The instruments used were instruments of DIT moral reasoning. The treatment was given six times for one and a half months. Thus, the data analysis used Kolmogorov Smirnov 2 Independent Samples to see the consistency of the treatment effect carried out.

\section{Result and discussion}

\subsection{Result}

It was found that the level of the students' moral reasoning was low. The data can be seen below. It was elaborated on the level of the students' moral reasoning. Group 1 was found in Table 1 where there were 12 people who had moral reasoning in the lower category. On the other hand, there were 14 students in group 2 who had moral reasoning in the lower category. After the treatment of both groups, the students' moral reasoning increased. Furthermore, post-test results concluded that 15 students in group 1 had moral reasoning in the high above category and 1 person was in the lower low category. On the contrary, there were 2 
students in group 2 had moral reasoning in the lower low category and there were 11 people had moral reasoning in the above high category.

Table 1. The Classification of Students' Moral Reasoning on Pre-test and Post-test

\begin{tabular}{clcccc}
\hline $\begin{array}{c}\text { Inter } \\
\text { val }\end{array}$ & Category & \multicolumn{2}{c}{ Group 1 } & \multicolumn{2}{c}{ Group 2 } \\
& & Pre-test & Post-test & Pre-test & Post-test \\
\hline$\geq 13$ & Very High & 3 & 15 & 3 & 11 \\
$10-12$ & High & 3 & 7 & 4 & 10 \\
$7-9$ & Low & 12 & 2 & 14 & 2 \\
$\leq 6$ & Very Low & 7 & 1 & 4 & 2 \\
\multicolumn{2}{r}{ Total } & 25 & 25 & 25 & 25 \\
\hline
\end{tabular}

Table 2. The Range Different of Group 1 and Group 2 Test

\begin{tabular}{llrr}
\hline \multicolumn{4}{c}{ One-Sample Kolmogorov-Smirnov Test } \\
\hline & & Group 1 & Group 2 \\
\hline $\mathrm{N}$ & & 4 & 4 \\
Normal Parameters & Mean & 6,2500 & 6,2500 \\
& Std. Deviation & 6,39661 & 4,92443 \\
Most Extreme Differences & Absolute &, 247 &, 306 \\
& Positive &, 247 &, 306 \\
& Negative &,- 206 &,- 277 \\
Kolmogorov-Smirnov Z & &, 494 &, 612 \\
Asymp. Sig. (2-tailed) & &, 968 &, 848 \\
\hline
\end{tabular}

a. Test distribution is Normal.

b. Calculated from data.

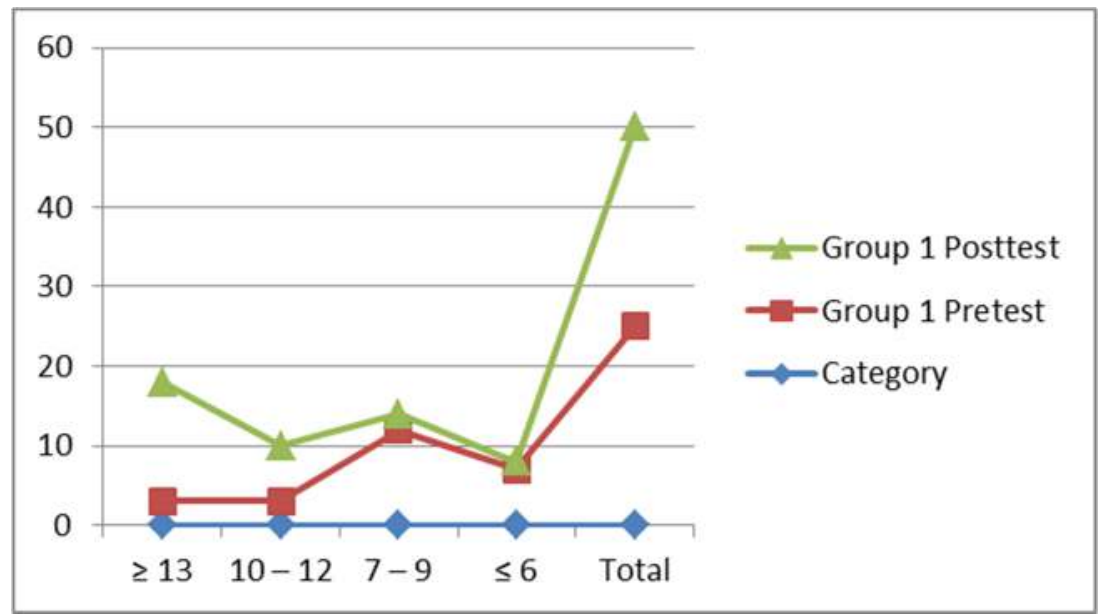

Fig. 1. The students' moral reasoning of group.

Based on graph 1 above, it was found that all respondents experienced an increase in moral reasoning after being given training in the material on effective and efficient of moral reasoning. The average increase of the students' moral reasoning in group 1 was 20.60 point. 


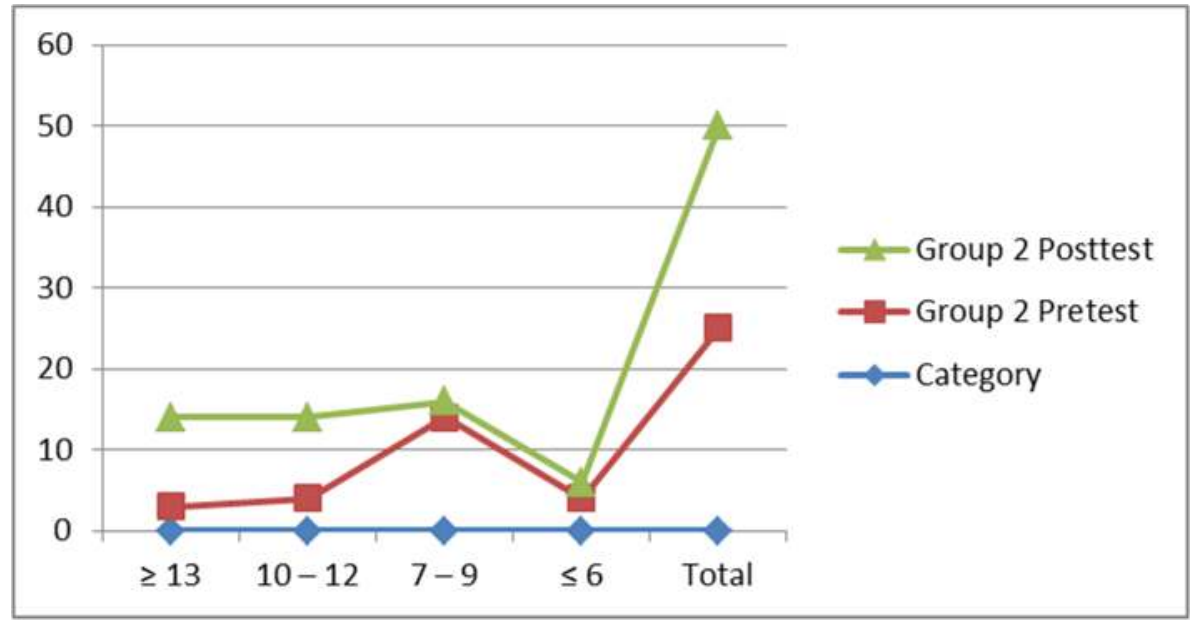

Figure 2. The students' moral reasoning of group.

Based on graph 2 above, it was found that all respondents experienced an increase in moral reasoning after being given training material on effective and efficient of moral reasoning education. The average increase of the students' moral reasoning in group 2 was 16.80 point. Kolmogorov-Smirnov Z test results found that Asymp.Sig. (2-tailed) in group 1 was equal to 0.968 . On the contrast, group 2 was 0.848 . Asymp value. Sig. (2-tailed) was greater than 0.05 significant value $(0.968>0.05)$ and $(0.848>0.05)$. This means that the results of the post-test of the two groups were the same. This conclusion meant that Counseling and Guidance services with intelligent character education of classical format model (PKC-KA) had the same effect on both groups. Thus, it was effective to improve the students' moral reasoning in college

\subsection{Discussion}

In the perfection and elevation of human status as creatures, God provides the basic characteristics of human existence and life, namely as social beings and as rulers of nature (khalifah on earth). These basic characters are integrated into human beings that are conceptualized as intelligent. First, the students must have intelligent characters because they are expected to become agents of change in society after completing their studies. Imagine if they do not have character, then they cannot be role models in society. The characters that they have to posses are courtesy, manners, tolerance, mutual cooperation, love and compassion, and democracy.

Secondly, as a ruler on the earth, they will become the successors of this generation. They are destined to be able to rule, as high as possible, under the rule of God. God implies that humans can go anywhere and achieve everything as long as they have strength. So, it is possible for them to be strong, as strong as possible. For the further explanation, what is strong? Does it mean as strong in physical or physical? The strength of the students is not only accumulated in their physicality, yet it is implied in intelligence too. With intelligence, humans can make what is needed in their lives, in advancing their lives, and in utilizing the contents of nature (inanimate objects, plants, and animals) for the growth and development of their lives. The development of abilities or strengths can be meant primarily through education. 
Education basically brings human life in accordance with the will of the Creator, God Almighty, according to the nature of human life itself. It is carried out from, for, and by humans, contains matters relating to development and human life and is held in inter-human relations. Based on the concept of human dignity (HMM) as social beings and as rulers of nature, general concepts about character indicators are more concretized by the term intelligent character. Ministry of National Education $(2011,6)$ explained that character education is an attempt to instill good habits (habituation) to make the students are able to behave and act based on the values that have become his personality.

\section{Conclusion}

- The guidance and counseling services with intelligent character education of classical format model (PKC-KA) is very effective to improve the students' moral reasoning.

- The students' moral reasoning which can be said as a person's ability to achieve a higher cognitive level and make them to think more complex is generally still in the low category. However, high morality can bring about change in society, nation, and state because the students have great potential, challenges, and responsibilities in the era of globalization.

\section{Acknowledgments}

Thank you to Universitas Negeri Padang for permitting the research.

\section{References}

[1] Papalia D E and Feldman R D 2014 Experience Human Development (Jakarta: Salemba Humanika)

[2] Kohlberg L 1984 The Psychology of Moral Development: The Nature and Validity of Moral Stages (San Francisco: Harper \& Row)

[3] Saragi, Iswari M and Mudjiran 2016 Konselor 51

[4] Stevani H, Mudjiran, M and Iswari M 2016 Konselor 515

[5] Prayitno and Khaidir A 2010 Model Pendidikan Karakter-Cerdas (Padang: Universitas Negeri Padang)

[6] Prayitno 2017 Pelatihan Pendidikan Karakter Cerdas (PKC-KO) (Padang: Universitas Nenegeri Padang) 